\title{
Rozwój pęknięć przy cyklicznym zginaniu dla różnych materiałów platerowanych wybuchowo
}

\author{
Cracks growth under cyclic bending \\ for different materials made by explosive cladding
}

\section{Streszczenie}

W pracy opisano rozwój pęknięć zmęczeniowych dla trzech różnych bimetali uzyskanych metodą zgrzewania wybuchowego. W każdym przypadku był jednakowy materiał podstawowy - stal węglowa $\mathrm{P} 355 \mathrm{NH}$, zaś materiały nakładane to: stale austenityczne $316 \mathrm{~L}, 254$ SMO oraz super duplex (50\% struktury ferrytycznej, $50 \%$ struktury austenitycznej). Próbki o przekroju poprzecznym prostokątnym poddano badaniom zmęczeniowym na zginanie przy średniej wartości naprężenia równej zero i o stałej amplitudzie momentu równej $19,41 \mathrm{~N} \cdot \mathrm{m}$. Propagacja pęknięcia mierzona była za pomocą przenośnego mikroskopu z mikrometrem znajdującym się przy maszynie zmęczeniowej.

Słowa kluczowe: zgrzewanie wybuchowe; stale, zginanie; zmęczenie; twardość

\begin{abstract}
This paper describes fatigue cracks growth in three different bimetallic made by explosive cladding. In any case, it was the same base material - carbon steel P355NH, and clad materials are: austenitic stainless steel 316L, 254SMO and super duplex (50\% ferritic structure, $50 \%$ of the austenitic structure). Specimens of rectangular cross-section was subjected to fatigue bending with of the stress mean value equal zero and of constant amplitude equal to $19.41 \mathrm{~N} \cdot \mathrm{m}$. The crack propagation was measured using a portable microscope with a micrometer located on the fatigue stand
\end{abstract}

Keywords: explosive welding; steels; bending; fatigue; hardness

\section{Wstęp}

Dzięki metodzie platerowania wybuchowego istnieje możliwość połączenia materiałów, których nie da się połączyć innymi metodami np. stal węglowa z aluminium bądź tytanem [1]. Połączenie materiałów następuje poprzez zderzenie materiału nakładanego z materiałem podstawowym z bardzo dużą prędkością $(2000-3500 \mathrm{~m} / \mathrm{s})$. Istotny jest dobór parametrów procesu platerowania, ponieważ zastosowanie zbyt małej bądź zbyt dużej prędkości może spowodować to, że materiały się nie połączą, bądź połączą się tylko częściowo. Materiały zgrzewane wybuchowo stosowane są w celu obniżenia kosztów poprzez połączenie materiału podstawowego, który jest stosunkowo tani z drogim materiałem nastrzeliwanym (np. cienka warstwa tytanu). Badania zmęczeniowe umożliwiają określenie trwałości zmęczeniowej materiałów, ponieważ wiele z nich pracuje w warunkach oddziaływania obciążeń zmiennych w czasie [2].

Celem niniejszej pracy są badania rozwoju pęknięć zmęczeniowych różnych materiałów uzyskanych metodą platerowania wybuchowego.

\section{Metodyka badań}

Badanymi materiałami są trzy platery: 1 - P355NH + 254SMO, 2 - P355NH + SAF2507, 3 - P355NH + 316L o wymiarach $520 \mathrm{~mm}$ x $800 \mathrm{~mm}$ wykonanych za pomocą zgrzewania wybuchowego przez Zakład Technologii Wysokoenergetycznych EXPLOMET Gałka, Szulc Sp. J. znajdujący się w Opolu. Jako pierwsze wykonane zostały badania nieniszczące ultradźwiękowe w celu sprawdzenia czy płyty są połączone na całej powierzchni. Badania te wykonane zostały po platerowaniu oraz drugi raz po prostowaniu blach. Wszystkie próbki pobrane zostały z tzw. zejścia detonacji, gdzie teoretycznie własności wytrzymałościowe są najgorsze. Materiałem podstawowym jest stal węglowa P355NH

Tablica I. Własności mechaniczne badanych materiałów przed połączeniem

Table I. Mechanical properties of materials before cladding

\begin{tabular}{|c|c|c|c|c|}
\hline Materiał & $\mathbf{R}_{\mathrm{e}}, \mathbf{M P a}$ & $\mathbf{R}_{\mathrm{m}}, \mathbf{M P a}$ & $\mathbf{A 5}, \%$ & $\mathrm{E}$ [GPa] \\
\hline P355NH & 415 & 555 & 30 & 212 \\
\hline $\begin{array}{c}\text { 254SMO } \\
(\mathbf{1})\end{array}$ & 350 & 690 & 35 & 200 \\
\hline $\begin{array}{c}\text { SAF2507 } \\
(\mathbf{2})\end{array}$ & 806 & 914 & 31 & 199 \\
\hline $\begin{array}{c}\text { 316L } \\
(\mathbf{3})\end{array}$ & 326 & 630 & 52 & 185 \\
\hline
\end{tabular}

Mgr inż. Grzegorz Kwiatkowski; dr hab. inż. Dariusz Rozumek, prof. nzw. PO - Politechnika Opolska.

Autor korespondencyjny/Corresponding author. d.rozumek@po.opole.pl 
o grubości $10 \mathrm{~mm}$ wykorzystywana w urządzeniach poddawanych działaniu ciśnienia. Materiałami nakładanymi o grubości $3 \mathrm{~mm}$ są stale austenityczne 254SMO i 316L wykorzystywane do urządzeń bądź konstrukcji mających styczność $z$ wodą i poddanych działaniu korozji. Ostatnim materiałem nakładanym jest super duplex SAF2507, którego znaczącą cechą jest ferromagnetyczność oraz odporność korozyjna. Własności mechaniczne łączonych materiałów przed platerowaniem przedstawiono w tablicy I.

Wykonane platery zostały poddane badaniom wytrzymałościowym takim jak: próba zginania, ścinania, rozciągania oraz udarność według normy ASTM A-264 [5]. Kolejnym etapem badań były badania zmęczeniowe na zginanie przeprowadzone na maszynie zmęczeniowej MZGS-100 znajdującej się na Politechnice Opolskiej. Badania wykonano w zakresie wysokiej liczby cykli przy stałym obciążeniu z kontrolowaną siłą (stała amplituda momentu $\mathrm{Ma}=$ $19,41 \mathrm{~N} \cdot \mathrm{m}$ ) i częstotliwością obciążenia $28,4 \mathrm{~Hz}$. Inicjacja i rozwój pęknięć zmęczeniowych mierzony był na bocznych powierzchniach próbek za pomocą mikrometru umieszczonego w przenośnym mikroskopie o powiększeniu 25x z dokładnością 0,01 mm, notując jednocześnie bieżącą liczbę cykli obciążenia N. Pęknięcie mierzono do momentu zniszczenia próbek, obserwując jednocześnie drogę pęknięcia do złącza $[2,3]$. Kształt oraz wymiary próbek pokazano w pracy [3]. Badania metalograficzne prowadzono na mikroskopie skaningowym JEOL JCM-6000. Głównymi aspektami obserwacji na mikroskopie była ścieżka pęknięcia oraz parametry złącza (długość fali, wysokość fali, długość złącza oraz współczynnik równoważnej grubości przetopień - RGP). Schemat pomiarów złącza przedstawiony jest w pracy [4]. Kolejnymi przeprowadzonymi badaniami były badania rozkładu twardości. Badania wykonano metodą Vickersa na twardościomierzu INNOVATEST NEXUS 4000 przy obciążeniu 4,9 N (500 G).

\section{Wyniki badań $\mathrm{i}$ ich analiza}

Badania wytrzymałościowe wykazały zmiany własności po procesie zgrzewania wybuchowego, a wyniki pokazano w tablicy II. Połączenie materiałów spowodowało spadek wytrzymałości na rozciąganie materiału nakładanego w próbce nr 1 i 2, zaś w próbce nr 3 nastąpił wzrost wytrzymałości na rozciąganie. Każda próbka przekracza graniczną wartość podaną w normie wynoszącą 485-620 MPa.

W próbie zginania, w której materiał podstawowy był ściskany, a materiał nakładany rozciągany, żadna próbka nie uległa rozwarstwieniu, co oznacza dobrą jakość złącza. Jeżeli chodzi o próbę ścinania wszystkie wyniki spełniają zalecenia normy, która mówi że minimalna siła ścinająca materiału nakładanego wynosi $140 \mathrm{MPa}$. Następnie przeprowadzono badania udarności. Według normy minimalna praca łamania musi wynosić $27 \mathrm{~J}$, co oznacza, że wszystkie trzy bimetale spełniają wymagania normy.

\section{Badanie rozwoju pęknięć zmęczeniowych}

W trakcie badań cyklicznego zginania obserwowano, za pomocą przenośnego mikroskopu, propagację pęknięć zmęczeniowych platerów. Przykładowe wyniki wzrostu pęknięć w funkcji liczby cykli pokazano na rysunku 1. Na podstawie rysunku 1 można zauważyć, że największą trwałość zmęczeniową wykazywały próbki $\mathrm{nr} 2$ i wynosiła ona Nf $=2674000$ cykli, natomiast najmniejszą trwałość zmęczeniową miała próbka $\mathrm{nr} 1(\mathrm{Nf}=475000$ cykli), gdzie materiałem nakładanym była stal 254SMO. W próbce nr 1, gdzie materiałem nakładanym jest stal 254SMO inicjacja pęknięcia nastąpiła w materiale podstawowym przy 437000 cykli, następnie pęknięcie propagowało w kierunku materiału nakładanego, aż do momentu przecięcia złącza (rys. 2).

Pęknięcie dotarło do złącza przy 471000 cykli, następnie nieznacznie rozwarstwiło złącze po czym pojawiło się drugie pęknięcie w odległości około $100 \mu \mathrm{m}$ od głównego pęknięcia. Pęknięcia te połączyły się w materiale nakładanym w odległości około 0,2 mm od złącza. Następnie pęknięcie propagowało $\mathrm{w}$ materiał nakładanym aż do powstania złomu próbki przy 475000 cykli. W przypadku próbki nr2,gdzie materiałem nakładanym jest super duplex SAF2507 inicjacja pęknięcia nastąpiła po 2614000 cykli również w materiale podstawowym, a następnie pęknięcie propagowało w kierunku materiału nakładanego. Pęknięcie dotarło do złącza przy 2663000 cykli, rozwarstwiło złącze w obu kierunkach na długości około 0,3 mm. Na rysunku 3 pokazano, że z lewej strony pęknięcie rozwarstwiło złącze jak również

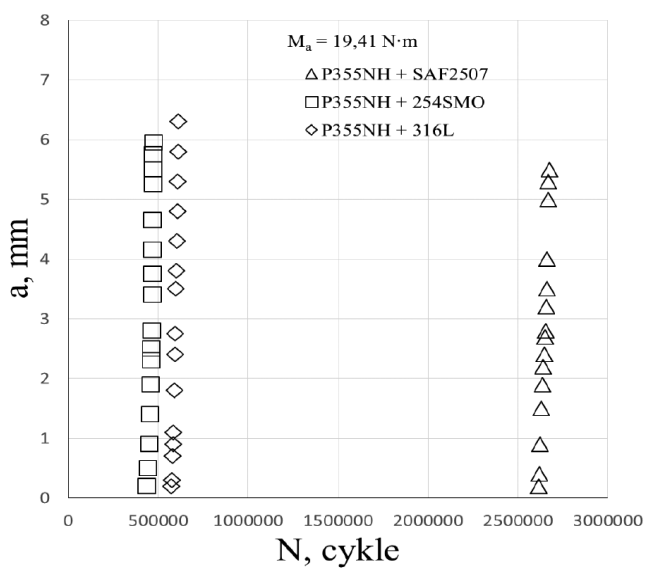

Rys. 1. Długości pęknięć w funkcji liczby cykli

Fig. 1. Cracks length vs. number of cycles

Tablica II. Własności mechaniczne badanych materiałów po połączeniu

Table II. Mechanical properties of materials after cladding

\begin{tabular}{|c|c|c|c|c|c|c|}
\hline \multirow[b]{2}{*}{ Próbka } & \multicolumn{3}{|c|}{ Wytrzymałość na rozciąganie } & \multirow{2}{*}{$\begin{array}{c}\text { Wytrzymałość } \\
\text { na ścinanie } \\
R_{s}, \mathrm{MPa}\end{array}$} & \multirow{2}{*}{$\begin{array}{c}\text { Wytrzymałość } \\
\text { na zginanie } \\
\begin{array}{c}\text { kąt zginania } \\
180^{\circ}\end{array}\end{array}$} & \multirow{2}{*}{$\begin{array}{c}\text { Udarność } \\
\begin{array}{c}\text { Wartość śred- } \\
\text { nia [J] }\end{array}\end{array}$} \\
\hline & $\mathrm{R}_{\mathrm{e}}, \mathrm{MPa}$ & $\mathbf{R}_{\mathrm{m}}, \mathrm{MPa}$ & $A_{50}, \%$ & & & \\
\hline 1 & 595 & 667 & 29 & 601 & \multirow{3}{*}{ Bez wad } & 52 \\
\hline 2 & 689 & 717 & 25 & 667 & & 67 \\
\hline 3 & 509 & 658 & 26 & 602 & & 60 \\
\hline
\end{tabular}




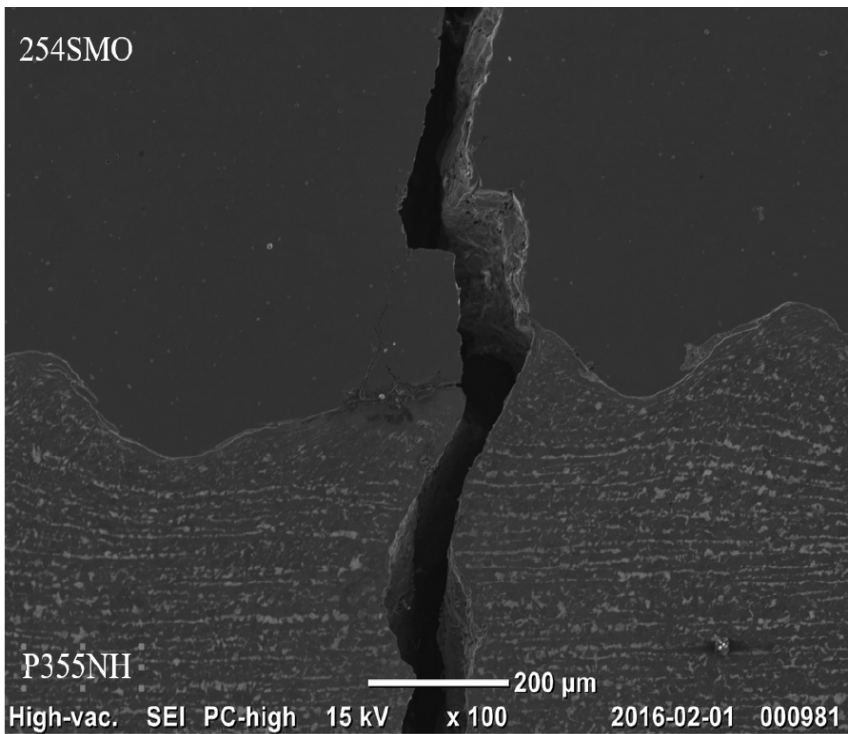

Rys. 2. Pęknięcie próbki oraz strefa złącza próbki P355NH + 254SMO Fig. 2. Crack specimen and area of joint specimen P355NH + 254SMO

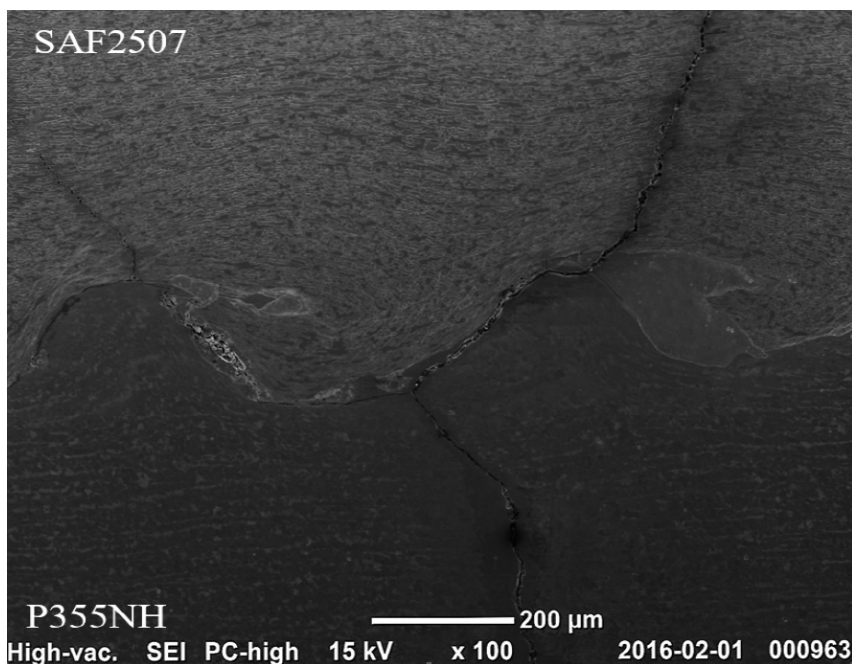

Rys. 3. Pęknięcie próbki oraz strefa złącza próbki P355NH + SAF2507 Fig. 3. Crack specimen and area of joint specimen P355NH + SAF2507

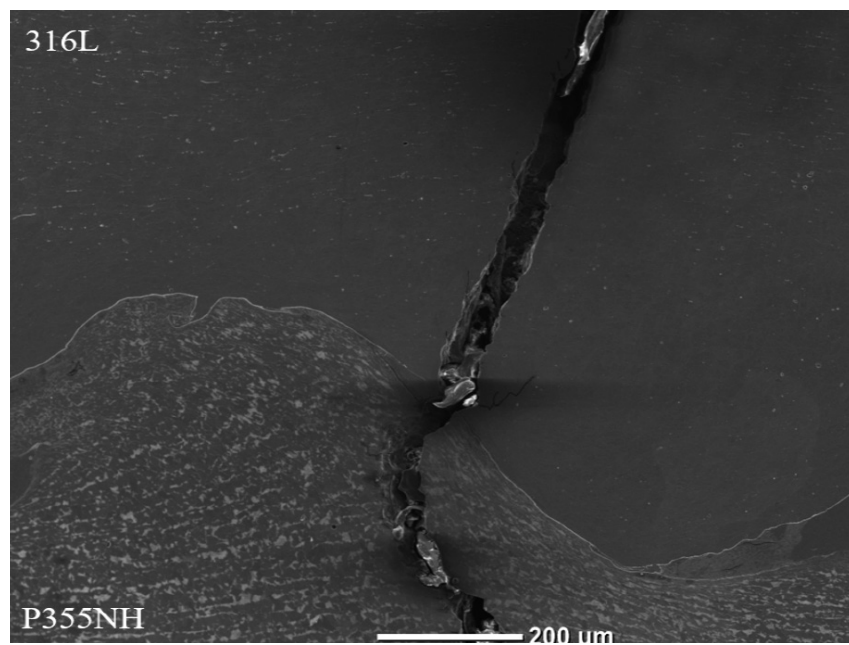

Rys. 4. Pęknięcie próbki oraz strefa złącza próbki P355NH + 316L Fig. 4. Crack specimen and area of joint specimen P355NH $+316 \mathrm{~L}$

przetopienie, a następnie propagowało w materiał nakładany. Z prawej strony pęknięcie rozwarstwiło złącze po czym przecięło przetopienie i również propagowało w materiale nakładanym. Plater ten cechuje się zdecydowanie większą trwałością zmęczeniową w porównaniu do plateru 1 i 3 . Trwałość zmęczeniowa plateru nr 3 jest nieco większa w porównaniu do próbki nr 1 i wynosi Nf = 611000 cykli. Pęknięcie inicjowało, przy 571000 cykli, od strony materiału podstawowego i propagowało w stronę materiału nakładanego (rys. 4). Pęknięcie dotarło do złącza przy 606000 cykli po czym przecięło złącze nie rozwarstwiając go i propagowało w materiał nakładany. W wielu miejscach w materiale nakładanym na ścieżce pękania głównego pojawiały się tzw. pęknięcia wtórne rozchodzące się w materiale.

\section{Badania geometrii złącza}

Wyniki pomiarów przedstawiono w tablicy III. Pomiary złącza wykazały, że próbka 2 ma najniższą jakość gdyż współczynnik RGP w tej próbce był najwyższy i wynosił 10,82. Jednak trwałość zmęczeniowa tej próbki w porównaniu do dwóch pozostałych jest największa. Przyczyny takiego rozwoju pęknięć należy doszukiwać się w zdefektowanej sieci krystalograficznej, gdzie wiązania międzyatomowe są najsłabsze. W przypadku próbki nr 2 pęknięcia rozwijały się w warstwie przetopionej (kruchej), które powodowały relaksację naprężeń w bimetalu i tym samym wpływały na wzrost trwałości zmęczeniowej. Najwyższa średnia wysokość fali występuje w próbce $\mathrm{nr} 3 \mathrm{i}$ wynosi $0,25 \mathrm{~mm}$, a współczynnik RGP = 5,94, co oznacza że złącze charakteryzuje się dobrą jakością. Próbka nr $1 \mathrm{ma}$ najniższy współczynnik RGP oraz najniższą wysokość fali (tablica III), a jej trwałość zmęczeniowa jest najmniejsza.

\section{Badania twardości}

Badania twardości wykonane zostały metodą Vickersa przy obciążeniu $500 \mathrm{G}$. Pomiary wykonano co $0,2 \mathrm{~mm}$ do $2 \mathrm{~mm}$ w głąb materiału podstawowego i nakładanego. Wyniki twardości pokazano na rysunku 5. Stwierdzono że w przypadku materiału podstawowego w obszarze złącza następuje niewielki wzrost twardości w każdej próbce. Oddalając się od złącza twardość jest bardzo zbliżona do materiału przed platerowaniem. W przypadku każdego materiału nakładanego nastąpił zdecydowany wzrost twardości w porównaniu z twardością przed platerowaniem. Próbka $\mathrm{nr} 1 \mathrm{w}$ odległości $0,2 \mathrm{~mm}$ od złącza posiada największą wartość twardości wynoszącą 435 HV0,5, następnie $w$ dalszej odległości twardość spada. Jednak $2 \mathrm{~mm}$ od złącza twardość jest w dalszym ciągu zdecydowanie większa, niż przed platerowaniem. Może być to spowodowane umocnieniem materiałów podczas samego procesu zgrzewania wybuchowego. Twardość próbki nr 2 w pobliżu złącza jest porównywalna z próbką nr 1 . Natomiast na całej badanej powierzchni nastąpił zdecydowany wzrost twardości w porównaniu z materiałami przed platerowaniem. Twardość próbki nr 3 również jest zdecydowanie większa od twardości przed platerowaniem.

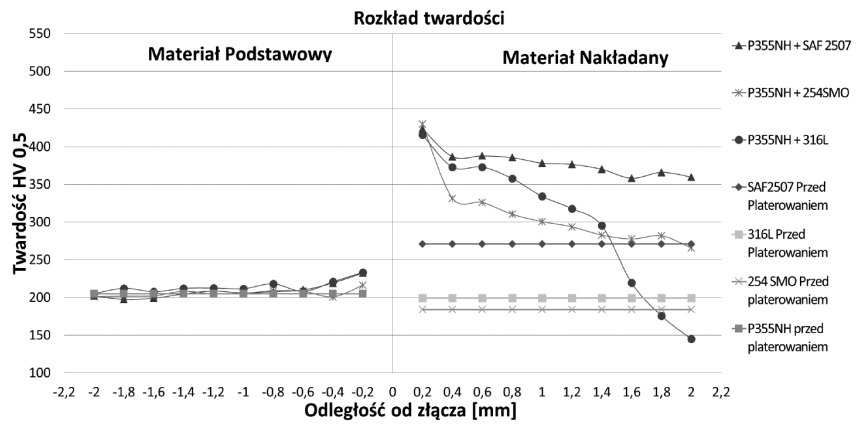

Rys. 5. Rozkład twardości w przekroju poprzecznym badanych złączy

Fig. 5. Distance from interface vs. hardness variation of investigated joints 
Tablica III. Wyniki pomiarów złącza

Table III. The measurement results of joint

\begin{tabular}{|c|c|c|c|c|c|}
\hline Próbka & $\begin{array}{c}\text { Średnia długość } \\
\text { fali } \boldsymbol{\lambda}, \\
\boldsymbol{\mu m}\end{array}$ & $\begin{array}{c}\text { Średnia } \\
\text { wysokość fali h, } \\
\boldsymbol{\mu m}\end{array}$ & $\begin{array}{c}\text { Pomiarowa } \\
\text { długość linii } \\
\text { złącza L, } \\
\boldsymbol{\mu m}\end{array}$ & $\begin{array}{c}\text { Suma } \\
\text { powierzchni } \\
\text { przetopień S, } \\
\boldsymbol{\mu m} \mathbf{m}^{2}\end{array}$ & $\begin{array}{c}\text { Wartość } \\
\text { współczynnika } \\
\text { RGP }\end{array}$ \\
\hline $\mathbf{1}$ & 326,46 & 72,62 & 8483,22 & 40493,28 & 4,77 \\
\hline $\mathbf{2}$ & 518,14 & 130,49 & 7905,49 & 85522,46 & 10,82 \\
\hline $\mathbf{3}$ & 684,41 & 251,45 & 12582,65 & 74749,53 & 5,94 \\
\hline
\end{tabular}

\section{Wnioski}

Na podstawie przeprowadzonych badań można sformułować następujące wnioski:

- Stwierdzono wzrost twardości w materiałach nakładanych po procesie platerowania wybuchowego.

- W wyniku zgrzewania wybuchowego uzyskano dobrej jakości połączenia, co potwierdzają otrzymane wyniki badań wytrzymałościowych.

- Z badań cyklicznego zginania wynika, że największą trwałość zmęczeniową posiada próbka, w której materiałem nakładanym jest super duplex SAF2507.

- W przypadku badanych próbek pęknięcie nastąpiło w materiale podstawowym i propagowało w stronę materiału nakładanego.

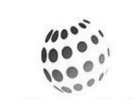

M-era.Net

\section{Praca powstała z wykorzystaniem części badań prowadzonych w ramach programu M-Era.net} „Nowe, odporne korozyjnie materiały wytworzone metodą wybuchową dla zastosowań w instalacjach geotermalnych".; współfinansowany z środków NCBiR decyzją numer DZP/M-ERA.NET-2013/2309/2014.

\section{Literatura}

[1] Crossland B., Explosive welding of metals and its application, Claredon Press, Oxford, 1982

[2] Prażmowski M., Paul H., Rozumek D., Marcisz E., Influence of the microstructure near the interface of the fatigue life of explosively welded (carbon steel)/Zr clads, Key Engineering Materials, Vols. 592-593, 2014, pp. 704-707.

[3] Bański R., Rozumek D. Wpływ temperatury wygrzewania na trwałość zmęczeniową w bimetalach stal - tytan otrzymanych metodą zgrzewania wybuchowego. Przegląd Spawalnictwa 4/2014.
[4] Kwiatkowski G. Praca dyplomowa pt. Wpływ parametrów obróbki cieplnej na strukturę i właściwości złączy bimetalicznych stal - tytan. Opole 2013.

[5] ASTM A-264-03 Standard Specification for Stainless Chromium-Nickel Steel-Clad Plate. 